\title{
BEBERAPA FAKTOR YANG MEMPENGARUHI \\ KEJADIAN PRE-MENSTRUAL SYNDROME (PMS) \\ PADA REMAJA PUTRI DI SMAK TERANG BANGSA SEMARANG TAHUN 2016
}

\section{Some Affecting Factors That Influence Adolescent Pre-Menstrual Syndrome In Terang Bangsa Senior High School Semarang Year 2016}

\author{
Roro Kushartanti \\ Prodi S1 Kesehatan Masyarakat \\ STIKES HAKLI Semarang \\ rorokushartanti@gmail.com
}

\begin{abstract}
ABSTRAK
Latar Belakang : Pre-Menstrual Syndrome (PMS) merupakan sekelompok gejala fisik dan psikologis yang dialami oleh setiap wanita usia subur (WUS) antara 7-10 hari sebelum terjadinya menstruasi. Kejadian PMS merupakan gangguan yang sering terjadi pada WUS, namun dapat berdampak buruk apabila gejala dirasakan semakin berat. Bagi remaja, kejadian PMS dapat memberikan dampak dari tingkat ringan sampai berat pada aktivitas sosial dan juga prestasi di sekolah. Penelitan ini bertujuan untuk mengetahui beberapa faktor yang mempengaruhi kejadian $P M S$ pada remaja putri di SMAK Terang Bangsa Semarang Tahun 2016.

Metode : Merupakan penelitian observational analytic dengan pendekatan cross sectional. Populasi dalam penelitian ini semua siswi kelas X dan XI sejumlah 234 orang. Sampel sejumlah 148 orang diperoleh dengan metode stratifed sampling.

Hasil : Hasil penelitian menunjukkan bahwa siswi yang mengalami kejadian PMS sebanyak 66 orang $(44,60 \%)$. Uji statistik menunjukkan bahwa riwayat keluarga ( $p$ value $=0,001 \mathrm{OR}=3,53 \mathrm{CI}=1,65-7,53)$ dan aktifitas fisik ( $p$ value $=0,033$ $\mathrm{OR}=2,16 \mathrm{CI}=1,07-4,37)$ berpengaruh terhadap kejadian $P M S$. Pola tidur $(p$ value $=0,105 \mathrm{OR}=1,80 \mathrm{CI}=1,89-3,64)$, status gizi ( $p$ value $=0,323 \mathrm{OR}=1,46$ $\mathrm{CI}=0,69-3,09)$, usia menarche ( $\mathrm{p}$ value $=0,699 \mathrm{OR}=1,19 \mathrm{CI}=0,54-2,64)$ dan umur ( $\mathrm{p}$ value $=0,244 \quad \mathrm{OR}=0,65 \mathrm{CI}=0,32-1,33$ ) tidak berpengaruh terhadap kejadian PMS pada remaja putri di SMAK Terang Bangsa Semarang Tahun 2016.

Simpulan : Ditemukan adanya pengaruh antara riwayat keluarga dengan kejadian $P M S$ dan antara aktifitas fisik dengan kejadian PMS. Saran dari peneliti kepada pihak sekolah agar dapat memberikan promosi kesehatan berupa penyuluhan ataupun pembuatan media kesehatan yang berkaitan dengan kejadian $P M S$, memperhatikan asupan gizi yang benar sesuai kebutuhan, aktifitas fisik (olah raga) yang teratur, serta pentingnya pola tidur yang baik dan cukup, yang mudah dipahami dan menarik bagi siswi.
\end{abstract}

Kata kunci : Pre-menstrual Syndrom (PMS), riwayat keluarga, aktifitas fisik 


\begin{abstract}
Background : Pre-Menstrual Syndrome (PMS) is a kind of physical and psychological symptoms happened by every woman of childbearing age (WCA) due to 7-10 days before menstruation phase. PMS phase is such a disturbance which often happened by every WCA, and getting worse with its symptom felt harder. For the teenies, PMS phase can be felt normal or harder according to their social activities and achievement at school. This research aimed to analyse factors that influence to PMS to the schoolgirls at Terang Bangsa Christian Senior High School in 2016.

Method: The characteristic of the research is observational analytic, that used cross sectional approach. Population of the research were 234 schoolgirls and the samples were 148 schoolgirls.

Result: The result of the research showed that the girls that happened PMS were 66 people (44.60\%). Statistical test showed that family's history ( $p$ value $=0.001$ $O R=3.53 C I=1.65-7.53$ ) and physical activity ( $p$ value=0,033; $O R=2,16$; $C I=1,07-4,37)$, nutrition statues ( $p$ value $=0.323 ; \quad O R=1.46 ; C I=0.69-3.09$ ), menarche age ( $p$ value $=0.699$ OR=1.19 CI=0.54-2.64) and age ( $p$ value $=0.244$; $O R=0.65 ; C I=0.32-1.33$ ) didn't influent to PMS phase to the schoolgirls at Terang Bangsa Christian Senior High School in 2016.

Conclusion : The summary of the research was the finding of a relational influence between family's history to PMS and physical activity to PMS to the schoolgirls of Terang Bangsa Christian Senior High School in 2016. The advice of the research to the stakeholders hopefully they might gave some health promotions likes counceling or other medias that relevant to PMS, and the importance to pay attention to the nutrition intake, proper physical activities and right sleep habitual which interesting and easy to be understood.
\end{abstract}

Keywords: Pre-menstrual Syndrome (PMS), family's history, physical activities

\title{
PENDAHULUAN
}

Menstruasi adalah pelepasan dinding rahim (endometrium) yang disertai dengan perdarahan dan terjadi setiap bulannya dimulai pada pada usia 11-14 tahun. Menstruasi pertama kali (menarche) terjadi pada usia 12 - 16 tahun. Siklus menstruasi yang normal terjadi setiap 22-35 hari, dengan lamanya menstruasi selama 2-7 hari. Menstruasi atau pendarahan periodik normal uterus merupakan proses katabolisme yang terjadi akibat adanya pengaruh dari hormon hipofisis dan ovarium, seperti hormon estrogen dan progesteron. Umumnya menstruasi akan terjadi secara normal setiap bulan pada wanita usia subur (WUS). (Herawati, 2009)

Pre-menstrual syndrome (PMS atau sindrom pramenstruasi) merupakan keluhan-keluhan yang biasanya mulai satu minggu sampai beberapa hari sebelum datangnya haid, dan menghilang sesudah haid datang, walaupun kadang-kadang berlangsung terus sampai haid berhenti. Wanita usia subur (WUS) di dunia, pada dasarnya pernah mengalami $P M S$, sebanyak $90 \%$ wanita mengalami setidaknya 
satu gejala dalam beberapa siklus menstruasi selama masa usia subur mereka. Diantara para WUS tersebut, 5 - 10\% mengalami gejala $P M S$ yang bersifat sedang sampai berat. (Suparman, 2010)

Remaja dengan masa usia 10-19 tahun, merupakan masa yang khusus dan penting karena terjadinya pematangan organ reproduksi manusia dan sering disebut masa pubertas. Pacu tumbuh terjadi pada masa ini, selain itu juga timbul ciri-ciri seks sekunder, tercapai fertilitas dan terjadi perubahan-perubahan psikologik serta kognitif. ${ }^{4}$ Kejadian $P M S$ ternyata cukup banyak dan sangat bervariasi jenis gejalanya pada setiap individu. Khusus bagi remaja putri yang bersekolah, dapat mengganggu kualitas kesehatan, menurunnya daya konsentrasi, prestasi dan keaktifan kegiatan belajar di sekolah. Pernyataan ini diperkuat dengan dilakukannya penelitian oleh Delara dkk, yang menunjukkan bahwa siswi dengan gangguan PMS mengalami beberapa penurunan, seperti : kondisi mental, peran fisik dan fungsi sosial. Disamping itu $P M S$ yang berat juga dapat berhubungan dengan kasus bunuh diri, tingkat kecelakaan dan masalah kejiwaan akut. (Cahyaningsih, 2011)

Survey awal yang peneliti lakukan di SMAK Terang Bangsa Semarang melalui wawancara didapati pada 25 siswi dari 234 siswi seluruh murid wanita kelas X dan XI, dimana ke 25 siswi tersebut mengalami $P M S$ dengan keluhan yang berbeda, yaitu : pembesaran dan nyeri pada payudara, sakit kepala (terkadang sampai migraine), perut kembung dan mual, nyeri pinggul dan nyeri pinggang, pegal dan nyeri (disminorhea spasmodic), emosi tidak terkontrol dan cenderung marah tanpa sebab yang jelas merasa cemas dan gelisah hingga ketakutan, nafsu makan bertambah, gangguan pada kulit (muncul jerawat), konsentrasi berkurang dan hilang koordinasi. Dirasa perlu untuk mengetahui gejala dan faktor apa saja yang mempengaruhi terjadinya pre-menstrual syndrome tersebut dan dapat dilakukan penanganan atau pencegahan lebih lanjut. Hal inilah yang mendasari ketertarikan peneliti untuk melakukan penelitian "Beberapa faktor yang mempengaruhi kejadian Pre-Menstrual Syndrome (PMS) pada remaja putri di SMAK Terang Bangsa Tahun 2016".

\section{METODE PENELITIAN}

Penelitian ini merupakan observational analytic dengan pendekatan crosssectional. Populasi penelitian ini adalah semua siswi kelas X dan XI SMAK Terang Bangsa Semarang Tahun 2016, sejumlah 234 orang. Sampel yang akan digunakan untuk penelitian ini adalah bagian dari populasi yang memenuhi kriteria sampel yaitu kriteria inklusi (siswi kelas X dan XI SMAK Terang Bangsa, sudah menstruasi dan mengalami gejala $P M S$ menjelang datangnya menstruasi, yang melakukan aktivitas rutin minimal 2-3 hari sebelum dilakukan penelitian, pengambilan sampel dilakukan pada hari Rabu - Jumat, bersedia menjadi responden) dan ekslusi (tidak bersedia menjadi responden dan tidak hadir pada saat dilakukan pengumpulan data). Sampel sejumlah 148 orang diperoleh dengan menggunakan rumus Slovin dan metode pengambilan sampel berstrata (stratifed sampling). Sesudah langkah tersebut dilakukan, baru instrumen penelitian disebarkan kepada anggota sampel yang sudah terpilih. Instrumen yang 
digunakan dalam pengumpulan data pada penelitian ini adalah kuesioner, yang berisi daftar pertanyaan tertulis yang ditujukan kepada responden dan dipakai untuk memperoleh data tentang karakteristik responden. Analisa statistik menggunakan uji Regresi Logistik sederhana. Variabel bebas terdiri dari : riwayat keluarga, aktifitas fisik, pola tidur, status gizi, usia menarche dan umur. Variabel terikat yaitu kejadian $P M S$.

\section{HASIL DAN PEMBAHASAN}

1. Karakteristik Responden

a. Lama Pendarahan

Diagram 1 Distribusi Frekuensi Lama Pendarahan Responden

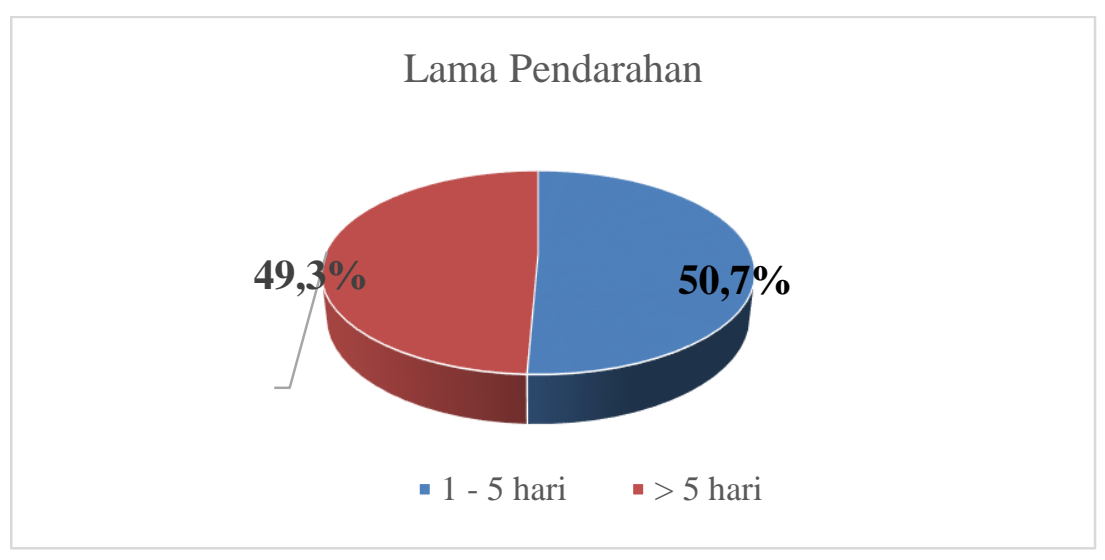

Berdasarkan Diagram 1 menunjukkan bahwa mayoritas responden mengalami lama pendarahan selama $>5$ hari sebanyak 75 responden.

b. Siklus Menstruasi

Diagram 2 Distribusi Frekuensi Siklus Menstruasi Responden

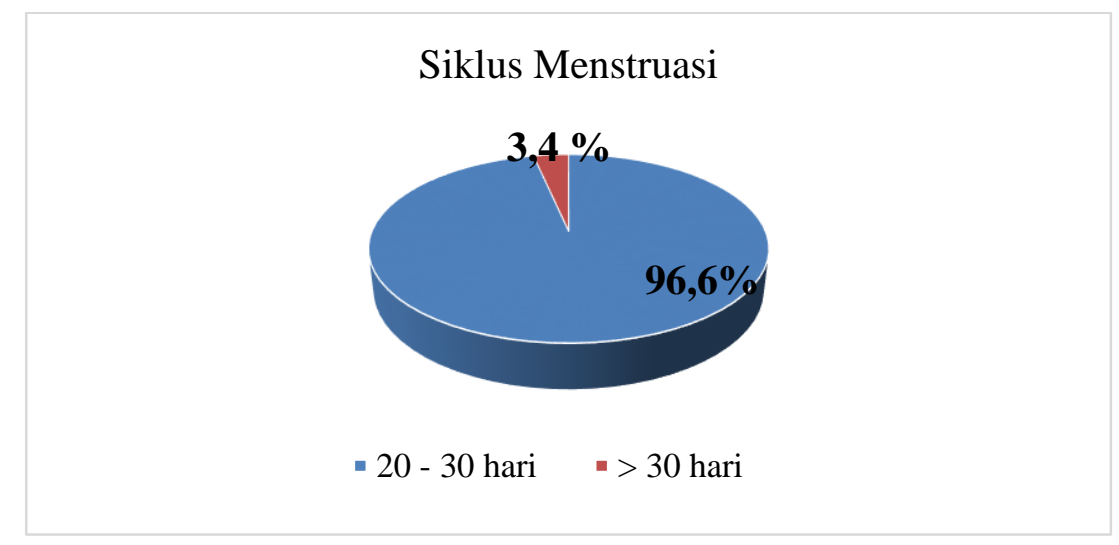

Berdasarkan Diagram 2 menunjukkan bahwa mayoritas responden mengalami siklus menstruasi selama 20 - 30 hari sebanyak 143 responden. 
c. Lama Gejala $P M S$

Diagram 3 Distribusi Frekuensi Lama Gejala PMS Responden

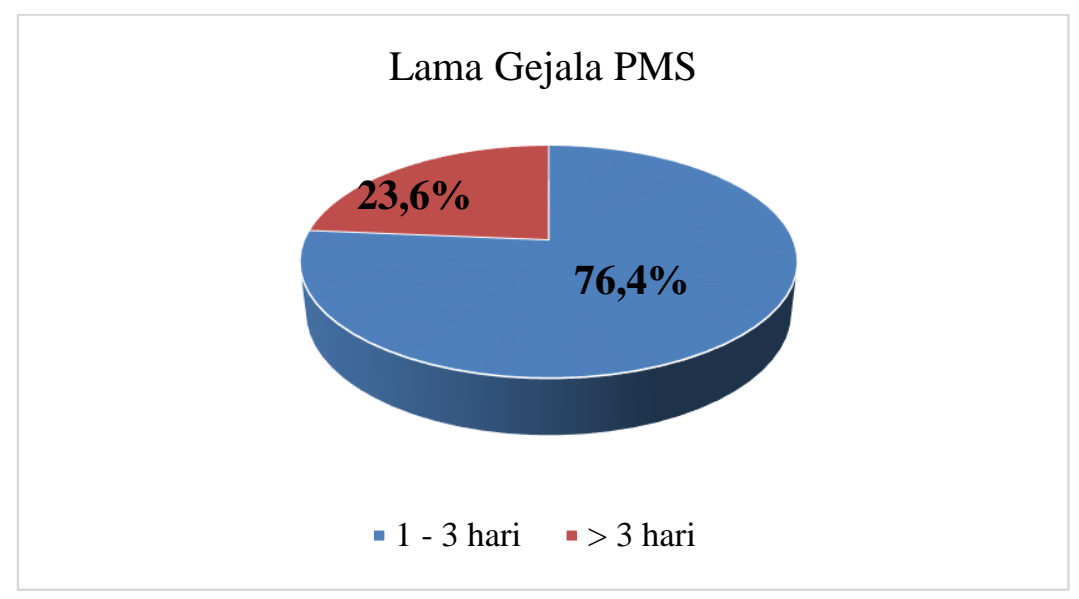

Berdasarkan Diagram 3 menunjukkan bahwa mayoritas responden mengalami lama gejala $P M S$ selama 1 - 3 hari sebanyak 113 responden.

2. Riwayat Keluarga

Diagram 4 Distribusi Frekuensi Responden Berdasarkan Riwayat Keluarga

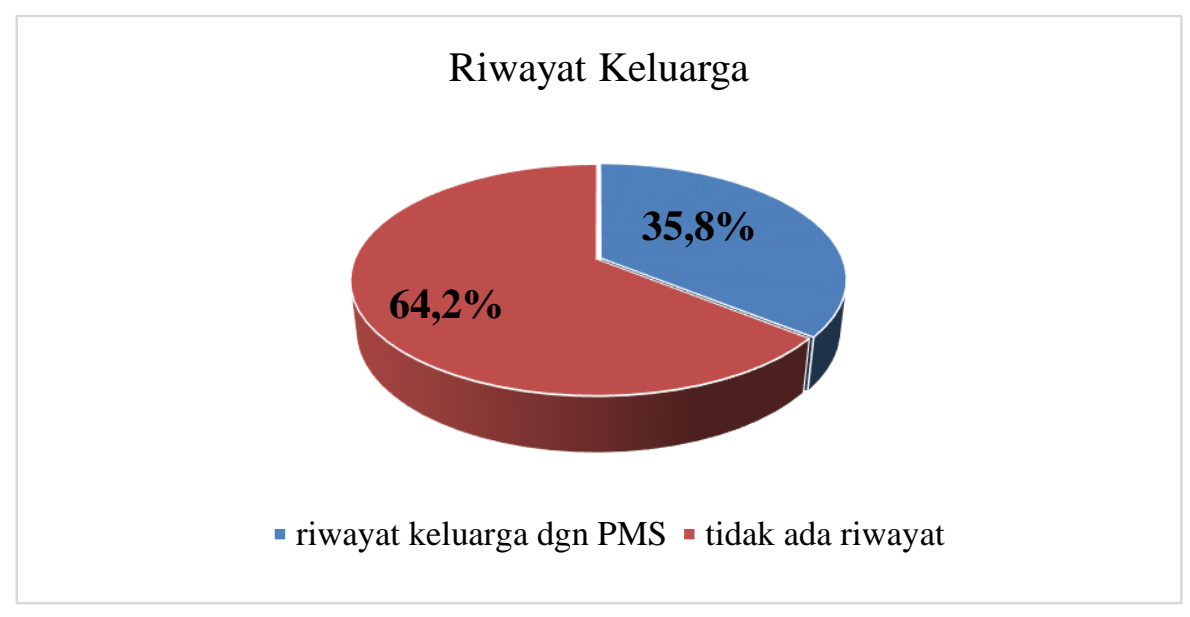

Berdasarkan Diagram 4 menunjukkan bahwa mayoritas responden tidak memiliki riwayat keluarga yang mengalami $P M S$ sebanyak 95 responden. Pada hasil uji statistik bivariat yang dibuktikan dengan uji regresi logistik didapatkan nilai $p<0,005(p=0,001)$, sehingga dapat disimpulkan bahwa riwayat keluarga berpengaruh terhadap kejadian $P M S$. Nilai $\mathrm{OR}=3,52(\mathrm{CI}=1,65-7,52)$ artinya responden dengan riwayat keluarga yang pernah mengalami gejala $P M S$ akan berisiko terkena $P M S$ sebesar 3 kali dibandingkan dengan responden yang tidak memiliki riwayat keluarga yang pernah mengalami gejala $P M S$.

Amjad dkk dalam penelitiannya menemukan bahwa ada pengaruh antara riwayat keluarga terhadap kejadian $P M S$, karena adanya faktor 
biologis yang diturunkan dari keluarga, karena genetik merupakan faktor yang memainkan peran penting pada kejadian $P M S$ yang memiliki hubungan yang sangat erat dengan perubahan hormon dan serotonin dalam tubuh. Ketidakseimbangan estrogen merupakan salah satu faktor utama yang dapat menyebabkan $P M S$. Adanya kelebihan estrogen dalam fase luteal (paska ovulasi) akan menyebabkan $P M S$. Dari berbagai pernyataan diatas dapat disimpulkan bahwa riwayat keluarga merupakan salah satu faktor yang berpengaruh terhadap kejadian PMS. (Amjad, 2014)

3. Aktifitas Fisik

Diagram 5 Distribusi Frekuensi Responden Berdasarkan Aktifitas Fisik

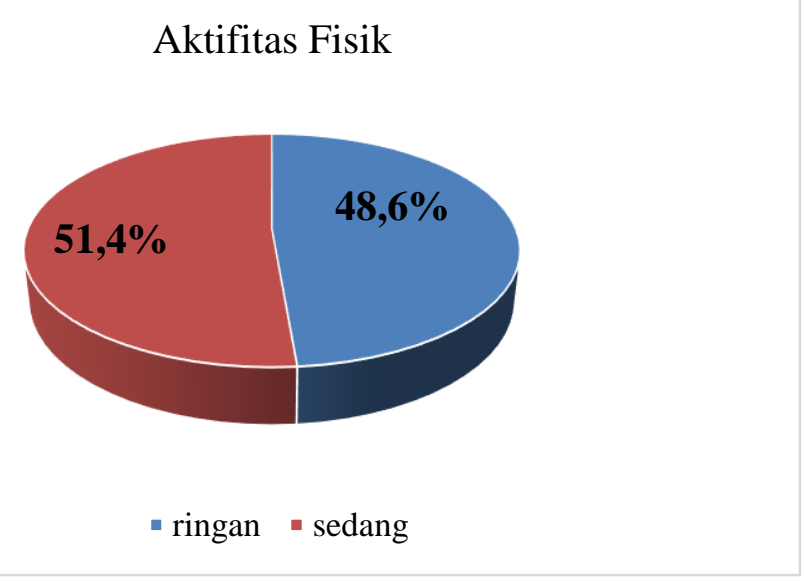

Berdasarkan Diagram 5 menunjukkan bahwa responden yang memiliki aktifitas fisik ringan sebesar 72 responden $(48,60 \%)$ dan yang memiliki aktifitas fisik sedang sebesar 76 responden $(51,40 \%)$. Dari hasil uji statistik bivariat didapatkan hasil nilai $p=0,033(p<0,05)$ yang berarti ada pengaruh antara aktifitas fisik terhadap kejadian $P M S$. Nilai $\mathrm{OR}=2,16$ (CI= 1,07-4,37), yang berarti bahwa responden yang memiliki aktifitas ringan berisiko 2 kali terkena $P M S$ dibandingkan dengan responden yang beraktifitas sedang.

Adanya aktivitas fisik yang teratur akan meningkatkan produksi endorfin, menurunkan kadar estrogen dan hormon steroid lainnya, sehingga dapat memperlancar transpor oksigen di otot, menurunkan kadar kortisol, dan meningkatkan perilaku psikologis. Selain itu juga disebutkan bahwa aktifitas fisik merupakan salah satu cara untuk meningkatkan kadar serotonin di otak, dimana serotonin ini berkaitan sangat erat dengan depresi dan perubahan mood yang berujung pada masalah kesehatan. (Stanley, 2007) 
4. Pola Tidur

Diagram 6 Distribusi Frekuensi Responden Berdasarkan Pola Tidur

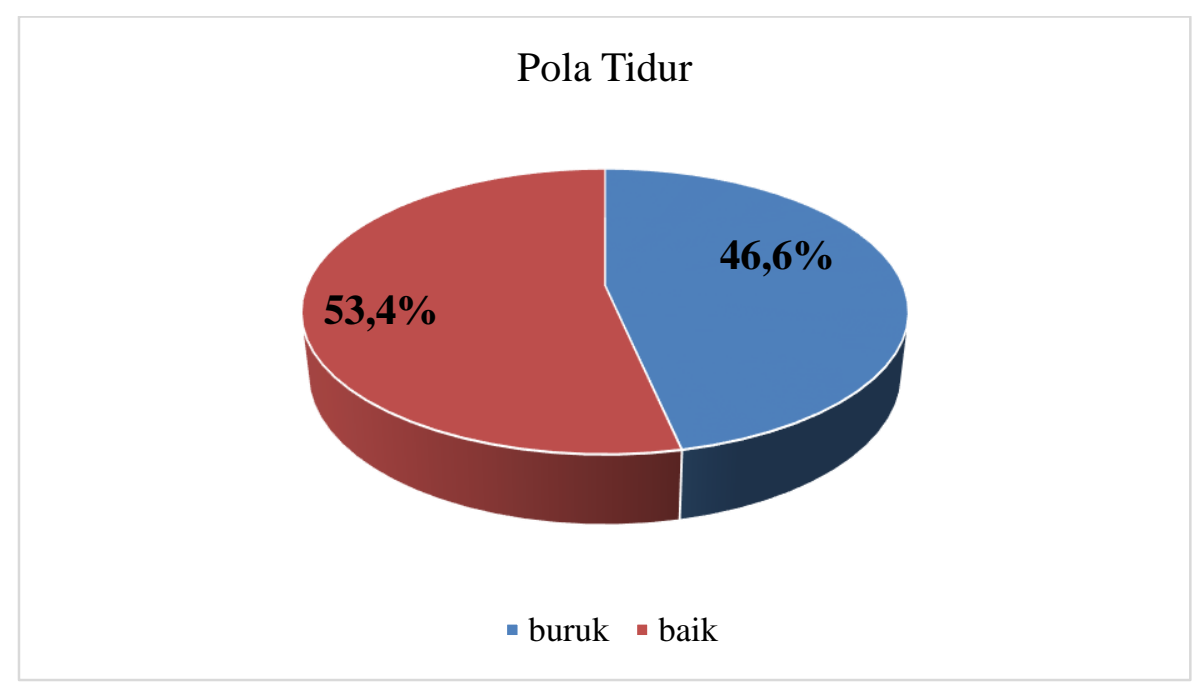

Berdasarkan Diagram 6 menunjukkan bahwa responden yang memiliki pola tidur buruk sebesar 69 responden $(46,60 \%)$ dan yang memiliki pola tidur baik sebesar 79 responden $(53,40 \%)$. Berdasarkan hasil uji statistik bivariat didapatkan hasil nilai $p=0,105(p>0,05)$ yang berarti tidak ada pengaruh antara pola tidur terhadap kejadian $P M S$. Nilai $\mathrm{OR}=1,80(\mathrm{CI}=0,89-3,64)$, menunjukkan bahwa pola tidur merupakan faktor risiko, yang berarti bahwa responden yang memiliki pola tidur buruk berisiko 2 kali terkena $P M S$ dibandingkan dengan responden yang memiliki pola tidur yang baik.

Penelitian ini tidak sejalan dengan penelitian yang dilakukan oleh Karaman dkk, yang menemukan bahwa baik buruknya kualitas tidur berpengaruh terhadap kejadian $P M S$. Responden yang memiliki pola tidur buruk lebih banyak yang mengalami kejadian $P M S$ dari sedang hingga berat, dibandingkan dengan responden yang memiliki pola tidur yang baik. Pola tidur yang baik (tidur tanpa gangguan) ternyata dapat meringankan gejala $P M S$, karena kualitas tidur sangat mempengaruhi sekresi berbagai hormon yang ada dalam tubuh. (Karaman, 2012) Tidak adanya pengaruh pola tidur terhadap kejadian $P M S$ pada remaja putri di SMAK Terang Bangsa Semarang, dapat dikarenakan pola tidur bukan satu-satunya faktor yang mempengaruhi kejadian PMS. Hal ini mungkin dapat disebabkan adanya faktor lain yang lebih dominan seperti faktor riwayat keluarga yang merupakan faktor genetik yang memegang peranan penting terhadap hormon estrogen dan serotonin, sebagai penyebab kejadian $P M S$, perbedaan dari metodologi yang digunakan antara penelitian ini dengan penelitian lainnya, dan juga dimungkinkan karena adanya faktor lain, misalnya adanya bias seleksi, yaitu dalam pengambilan sampel terjadi keseragaman (homogenitas). 
5. Status Gizi

Diagram 7 Distribusi Frekuensi Responden Berdasarkan Status Gizi

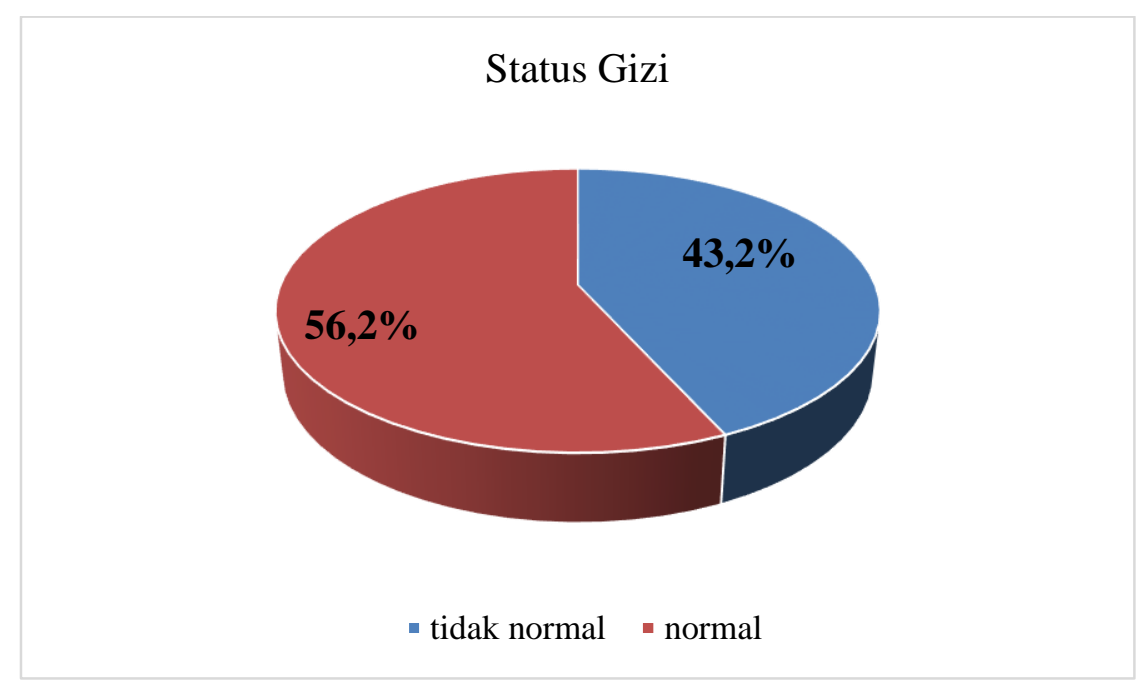

Berdasarkan Diagram 7 menunjukkan bahwa responden yang memiliki status gizi tidak normal sebesar 64 responden $(43,20 \%)$ dan yang memiliki status gizi normal sebesar 84 responden $(56,80 \%)$. Berdasarkan hasil uji statistik bivariat didapatkan hasil nilai $p=0,323(p>0,05)$ yang berarti tidak ada pengaruh antara status gizi terhadap kejadian $P M S$. Nilai OR sebesar 1,46 (CI= 0,69-3,09) menunjukkan bahwa status gizi merupakan faktor risiko yang berarti bahwa responden yang memiliki status gizi tidak normal akan berisiko 1 kali terkena $P M S$ dibandingkan dengan responden yang memiliki status gizi yang normal.

Penelitian diatas berbanding terbalik dengan penelitian oleh Aminah, yang menemukan ada pengaruh antara status gizi menurut IMT terhadap kejadian $P M S$, dimana siswi dengan status gizi tidak normal (obesitas, overweight atau under weight) memiliki kemungkinan mengalami PMS 3,3 kali lebih besar dibandingkan dengan siswi yang memiliki status gizi normal. Status gizi tidak normal (obesitas, overweight atau under weight) selain akan mempengaruhi pertumbuhan, fungsi organ tubuh, dapat menyebabkan terganggunya fungsi reproduksi yang berpengaruh terhadap kejadian $P M S$, tetapi akan membaik bila asupan nutrisinya baik. (Aminah, 2011)

Tidak adanya pengaruh status gizi terhadap kejadian $P M S$ pada remaja putri di SMAK Terang Bangsa Semarang, dapat juga dipengaruhi oleh faktor penyebab lain dalam kejadian $P M S$ seperti ketidakseimbangan hormon estrogen dan progesterone, faktor kejiwaan, faktor genetik, masalah sosial, dan gangguan fungsi serotonin, selain adanya faktor lain, misalnya adanya bias seleksi, yaitu dalam pengambilan sampel terjadi keseragaman (homogenitas). 
6. Usia Menarche

Diagram 8 Distribusi Frekuensi Responden Berdasarkan Usia Menarche

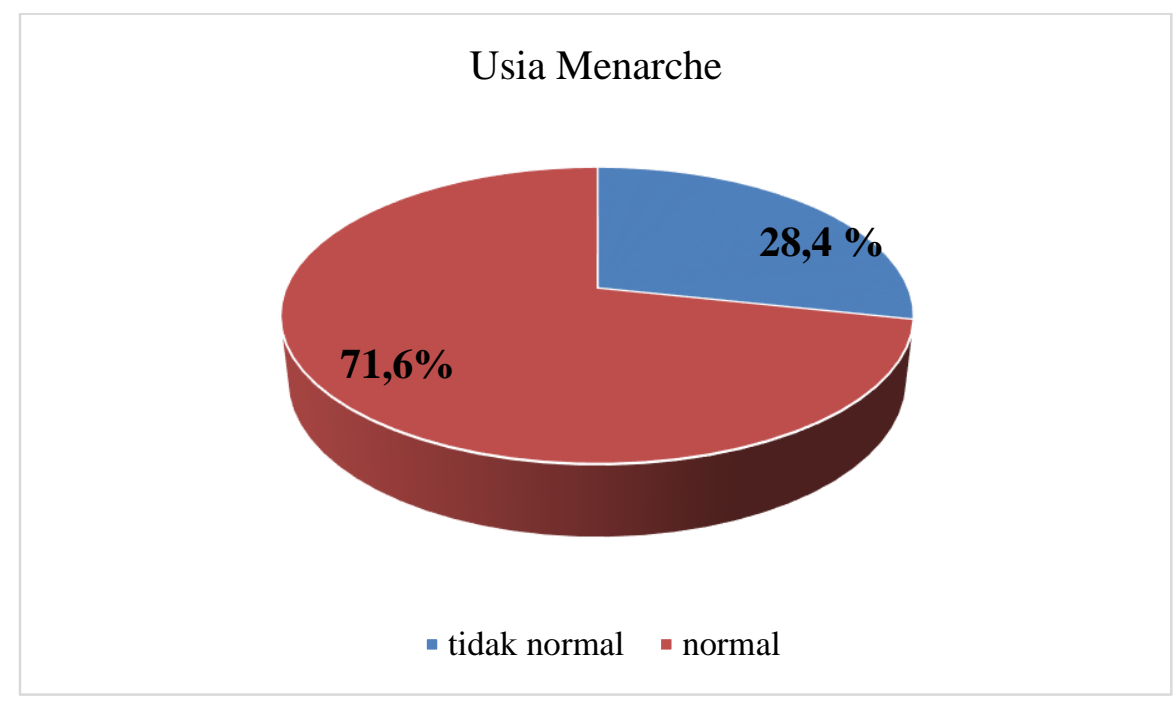

Berdasarkan Diagram 8 menunjukkan bahwa responden dengan usia menarche tidak normal sebesar 42 responden $(28,40 \%)$ dan responden dengan usia menarche normal sebesar 106 responden $(71,60 \%)$. Pada hasil uji statistik bivariat didapatkan hasil nilai $p=0,669(p>0,05)$, yang berarti tidak ada pengaruh antara usia menarche terhadap kejadian PMS. Nilai OR sebesar 1,19 (CI= 0,54-2,64) menunjukkan bahwa usia menarche merupakan faktor risiko, responden yang mengalami usia menarche tidak normal akan berisiko 1 kali terkena PMS dibandingkan dengan responden yang mengalami usia menarche normal.

Penelitian ini tidak sejalan dengan penelitian yang dilakukan oleh Aminah dkk, dimana diketahui bahwa terdapat hubungan ( $p$-value $<0,05)$ antara usia menarche dengan $P M S$. Siswi dengan usia menarche cepat ( $<11$ tahun) berisiko 2,3 kali lebih besar untuk menderita pre-menstrual syndrome (PMS) dibandingkan dengan siswi yang mengalami menarche lambat (>13tahun). Namun ada kemungkinan bahwa proses pematangan dari sisi fisiologi dan psikologi yang belum sepenuhnya sempurna pada awal fungsi ovariumlah yang mungkin bertanggung jawab atas hubungan tersebut. Pada umumnya seorang remaja, $P M S$ dimulai pada usia sekitar 14 tahun atau 2 tahun setelah menarche dan akan berlanjut sampai menopause, sehingga ketika menarche lebih cepat/dini, maka akan mengalami PMS lebih cepat pula. (Aminah, 2011)

Penyebab lain yang dimungkinkan menyebabkan tidak adanya pengaruh antara usia menarche dengan kejadian $P M S$ adalah dikarenakan faktor lain yang lebih dominan seperti faktor riwayat keluarga yang merupakan faktor genetik, yang memainkan peran penting terhadap hormon estrogen dan serotonin, dan juga faktor psikologis yang berhubungan dengan hormon progesteron yang merupakan penyebab utama dari kejadian $P M S$. 
7. Umur

Diagram 9 Distribusi Frekuensi Responden Berdasarkan Umur

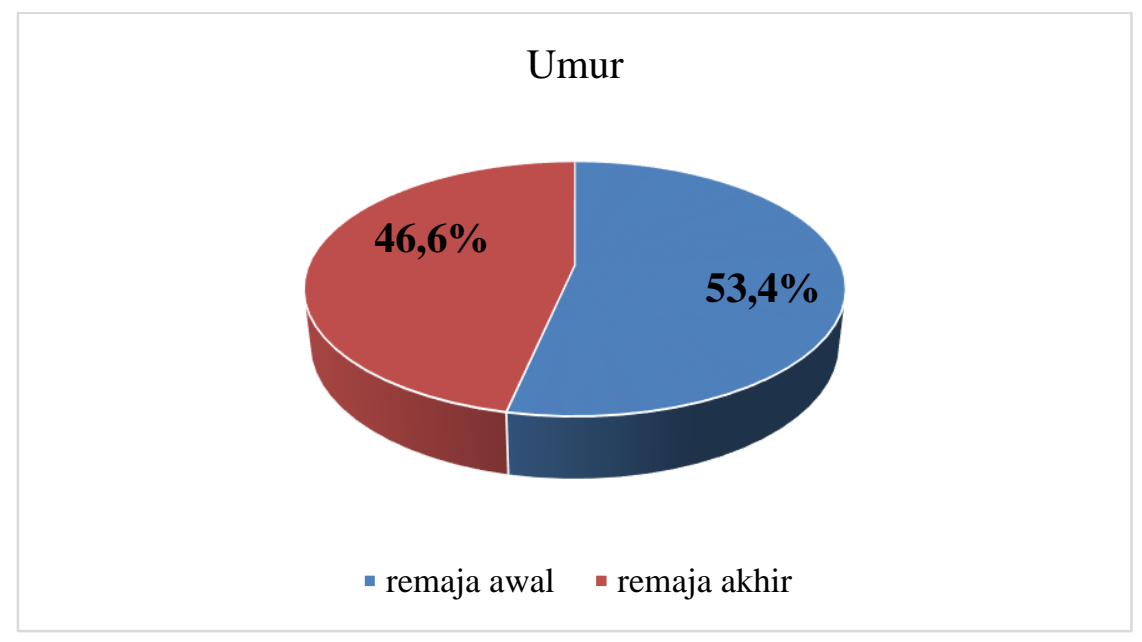

Berdasarkan Diagram 9 menunjukkan bahwa responden dengan umur remaja awal sebesar 79 responden $(53,40 \%)$ dan dengan umur remaja akhir sebesar 69 responden $(46,60 \%)$. Berdasarkan hasil uji statistik bivariat didapatkan hasil nilai $p=0,244(p>0,05)$ yang berarti tidak ada pengaruh antara umur terhadap kejadian $P M S$. Nilai OR sebesar 0,66 $(\mathrm{CI}=$ 0,32-1,33) menunjukkan bahwa umur merupakan faktor protektif, yaitu faktor yang berdampak positif terhadap responden. Dapat juga diartikan bahwa umur bukan merupakan faktor risiko yang dapat memperburuk kejadian $P M S$.

Hasil penelitian ini berbeda dengan hasil penelitian yang dilakukan oleh Amjad dkk, yang menyatakan bahwa umur menjadi salah satu faktor yang berkaitan dengan kejadian $P M S$. Amjad dkk., dalam penelitiannya menemukan adanya hubungan $(p<0,05)$ antara usia wanita dengan kejadian $P M S$, yaitu : wanita dengan rentang usia 15-24 tahun $(64,67 \%)$, wanita dengan rentang usia 25-34 tahun $(22,75 \%)$ dan wanita dengan rentang usia 35-45 tahun (12,75\%). (Amjad, 2014)

Namun perbedaan hasil penelitian ini sejalan dengan penelitian yang dilakukan oleh Maulana, yang menunjukkan bahwa faktor umur tidak berpengaruh dengan $P M S$, karena wanita usia remaja yang baru mengalami menstruasi masih terfokus pada gejala yang mereka alami sebelum menstruasi, sementara pada usia dewasa tidak terlalu dihiraukan karena pikiran mereka telah terpecah kepada hal selain PMS dan pada usia dewasa wanita dapat mengatur perubahan yang dialami oleh tubuh dengan baik untuk mengatasi gejala $P M S$ yang terjadi. Hal ini menunjukkan bahwa umur bukan merupakan faktor yang sangat mempengaruhi kejadian $P M S$, karena tingkat usia seseorang berpengaruh terhadap respon kesehatan, motivasi dan psikologi serta depresi. Rata-rata orang yang lebih tua akan mengalami lebih banyak depresi dan tekanan psikologi dibandingkan dengan yang muda, namun pada usia tua gangguan ini lebih 
cepat pulih dibandingkan dengan usia muda karena memiliki harapan dan kematangan mental yang lebih baik. (Maulana, 2008) Dari beberapa hasil penelitian diatas, dapat diambil kesimpulan bahwa seiring dengan peningkatan usia, risiko gangguan kesehatan juga semakin tinggi, akan tetapi pada kejadian $P M S$ tidak terlalu berpengaruh karena pada usia dewasa telah terjadi kematangan perkembangan emosional. Perkembangan emosional ini akan sangat berpengaruh terhadap respon serta tindakan seseorang terhadap status kesehatan.

\section{SIMPULAN DAN SARAN}

\section{Simpulan}

Berdasarkan penelitian mengenai beberapa faktor yang berpengaruh terhadap kejadian Pre-menstrual Syndrome (PMS) pada remaja putri di SMAK Terang Bangsa Semarang tahun 2016, didapatkan hasil bahwa variabel riwayat keluarga dan aktifitas fisik berpengaruh terhadap kejadian $P M S$ pada remaja putri di SMAK Terang Bangsa Semarang, sedangkan variabel pola tidur, status gizi, usia menarche, dan umur tidak mempengaruhi kejadian $P M S$ pada remaja putri di SMAK Terang Bangsa Semarang.

\section{Saran}

Bagi Klinik Terang Bangsa Semarang diharapkan dapat melakukan promosi kesehatan berupa penyuluhan kesehatan yang berkaitan dengan kejadian $P M S$ dan/atau pembuatan media kesehatan, seperti poster (yang bisa ditempel) yang berkaitan dengan kejadian Pre-menstrual Syndrome (PMS). Bagi Sekolah SMAK Terang Bangsa Semarang diharapkan dapat mengadakan kegiatan promosi kesehatan berupa penyuluhan kesehatan dan/atau pembuatan media kesehatan yang mudah dipahami yang berkaitan dengan kejadian $P M S$, mengadakan kegiatan yang melibatkan siswi untuk mengkomsumsi susu ataupun makanan bergizi, menyediakan perlengkapan penunjang sehubungan dengan kejadian $P M S$ yang dialami siswi selama sekolah berlangsung yang ditempatkan di UKS sekolah.

Bagi siswi SMAK Terang Bangsa Semarang diharapkan dapat mempertahankan kegiatan aktifitas fisik secara rutin setiap hari, memperbaiki kualitas tidur dengan cara memperhatikan lama durasi tidur dan mengurangi kegiatan yang menganggu seperti penggunaan gadget sebelum tidur, memperbaiki pola makan dengan rutin mengkomsumsi susu minimal 1 gelas / sehari dan tetap mengkomsumsi makanan yang mengandung banyak serat, seperti sayur dan buahbuahan.

Saran bagi peneliti lain diharapkan dapat melakukan penelitian lebih lanjut tentang pola tidur untuk mengatahui latar belakang buruknya pola tidur terutama pada remaja, dan dapat melakukan penelitian dengan menggunakan desain penelitian lain, seperti case control study yang dapat menggambarkan hubungan sebab akibat antar variabel penyebab kejadian PMS. 


\section{DAFTAR PUSTAKA}

Amjad, A., Kumar, R. Dan Mazher, S.B. 2014. Socio-demographic Factors and Premenstrual Syndrome among Women attending a Teaching Hospital in Islamabad, Pakistan. J Pioneer Med Sci, 4,4.

Stanley, M .2007. Buku Ajar Keperawatan Gerontik. Edisi II, Jakarta. Penerbit EGC.

Karaman, H.I.O., Tanriverdi G dan Degimency, Y. 2012. Subjective Sleep Quality in Premenstrual Syndrome. Journal Gyneacology Endoctionology, 28,5.

Aminah, S., Rahmadani, S. dan Munadhiroh. 2011. Hubungan Status Gizi dengan Kejadian Premenstrual Syndrome di Madrasah Aliyah Negeri (MAN) 4 Jakarta Tahun 2011. Healthy Quality Jurnal Kesehatan, 2

Maulana , R. 2008. Hubungan Karakteristik Wanita Usia Reproduktif dengan Premenstrual Syndrome (PMS) di Poli Obstetri 2008.Http::/razimaulana.files.wordpress.com/2008/12/pms.doc.c[diakses pada tanggal 01 Agustus $2016: 23.17$ WIB] 